a matter for conjecture, but the possibilities of transport from the estuaries of Holland or North Germany are obvious. Some highly coloured forecasts have appeared in the daily Press regarding the damage likely to be caused if the crab becomes established in English rivers and estuaries. It can safely be said, however, that there is little ground for apprehension. On the Continent, the banks of rivers have been undermined in places by the burrows of the crabs, but the most serious damage has been caused to fresh-water fishes. In Great Britain, where freshwater fish have for the most part only a sporting value, the new addition to the fauna may justify some anxiety on the part of anglers in the eastern counties. There is fortunately no reason for anticipat. ing that the crab will introduce into Europe the lung disease, paragonimiasis, of which it is one of the vectors in the Far East.

\section{Association of British Chemical Manufacturers}

THE nineteenth annual report of the Association of British Chemical Manufacturers, submitted to the annual meeting on October 10, records an increase in membership from 109 to 118 , while the number of affiliated associations is now 13. Reference is made to the participation of the Association in the Brussels International and Universal Exhibition, the British Chemical Exhibit at which has been organised by the Association at the request of the Department of Overseas Trade. The safety activities of the Association have been continued, and the Association has submitted a list of solvents in general use as a basis for the investigation, which has now been commenced by a special com. mittee under the Medical Research Council, on their physiological effects in relation to industrial risks. The investigation on tests for the detection of low concentrations of toxic gases that are likely to be encountered in industry, to which the Association has contributed half the cost, is nearing completion. Methods of detection and estimation, usually with test papers, have been worked out and standardised for a number of gases by the Chemical Defence Research Department, and a printing method has been discovered which will give consistent results and yield permanent stains. The Association is also supporting financially work on the testing of respirators for industrial use to ensure that they give adequate protection, which is being carried out by the Chemical Research Department. The Association has taken over from the Chemical and Allied Employers' Federation the regular collection and investigation of accident statistics as part of its normal safety activities. Other matters on which action has been taken during the year relate to the Provisional Poisons List and Poisons Rules and the report of the Poisons Board, trade marks, Government patents and the transport of chemicals by road.

IN moving the adoption of the report at the annual meeting, Mr. T. Wallace, who deputised as chairman in the absence of Dr. F. H. Carr, through illness, referred particularly to the manner in which the Government left the chemical section of the Polish
Treaty to be worked out between the Association and the Polish Union of Chemical Industries. The importance of industrial reorganisation was stressed, particularly the necessity for further co-operation in regard to research, production and marketing. Commenting on the position of the fine chemical industry, Mr. Wallace said that since the report was written a supplementary memorandum has been submitted to the Key Industries Committee of the Board of Trade, detailing reasons why the manufacturers considered the progressive development of the industry would be better assured by a continuance of the key industry duties than by a transfer to the Import Duties Act.

\section{Roman Yorkshire}

As progress is made in the excavation of the Roman villa at Rudston, six miles west of Bridlington in Yorkshire, it affords a more extended view of settled life under what has been termed the 'signal-station' system, which archæological discovery in this area has revealed as a characteristic feature in the organisation of this section of Roman Britain. The site has now been under investigation for three seasons by a local committee in conjunction with the Roman Antiquities Committee of the Yorkshire Archæological Society, the excavation being in charge of Messrs. A. M. Woodward and K. A. Steer. Both coins and types of pottery point to an occupation of considerable duration, the former ranging from Domitian to Valens, and the latter including late first century, Samian, third century types from the Yorkshire pottery at Throlam and 'signal-station' types of the end of the fourth century. A system of pre-Roman ditches below the foundations may go back so far as the Bronze Age. An interesting building to the west of the residential block, discovered in 1934, which measures not less than $50 \mathrm{ft}$. by $22 \mathrm{ft}$., is now seen, according to a report of the latest results of excavation (The Times, Oct. 22), to have been used for a variety of purposes connected with the needs of the villa. Tesserae of sandstone not of local origin, and many chippings of chalk and tile, confirm tho view suggested by earlier discoveries of chalk tesserae and red and blue tiles that it was a workshop for making and repairing mosaic flooring. Further, remains of no less than six ovens point to other uses not yet completely apparent. An early suggestion that they were part of the equipment for the manufacture of wool or for tanning has now been abandoned in favour of the view that they were for drying or roasting grain preparatory to grinding.

\section{The College of Science, Benares Hindu University}

Few countries are, in proportion to their literate population, so well equipped with modern laboratories as India. The reproach can no longer be levelled at Indian university education that it is purely literary. We need only cite as examples the fine laboratories to be found at the University College of Science, Calcutta, the Presidency College, Madras, and the Royal Institute of Science, Bombay. From the time of its foundation in 1911, the Hindu University at 